\title{
The Development of a New Kinetic Spectrophotometric Method for the Determination of Vanadium(V) Based on its Catalytic Effect on the Oxidation of Malachite Green Oxalate by Bromate in Acidic and Micellar Medium
}

\author{
M. KEYVANFARD* and N. ABEDI \\ *Faculty of Science,Islamic Azad University, Majlesi Branch, Isfahan, Iran. \\ Group of Chemistry,Islamic Azad University, shahreza Branch, Isfahan, Iran. \\ keyvan45638@yahoo.com
}

Received 4 February 2010; Accepted 1 April 2010

\begin{abstract}
A new, simple, sensitive and selective kinetic spectrophotometric method was developed for the determination of ultra trace amounts of $\operatorname{vanadium}(\mathrm{V})$. The method is based on the catalytic effect of vanadium $(\mathrm{V})$ on the oxidation of malachite green oxalate (MG) by bromate in acidic and micellar medium. The reaction was monitored spectrophotometrically by measuring the decrease in the absorbance of malachite green oxalate (MG) at $625 \mathrm{~nm}$ with a fixed-time method. The decrease in the absorbance of MG is proportional to the concentration of vanadium $(\mathrm{V})$ in the range of $1-100 \mathrm{ng} / \mathrm{mL}$ with a fixed time of 0.5-2 min from the initiation of the reaction. The limit of detection is $0.71 \mathrm{ng} / \mathrm{mL}$ of vanadium(V). The relative standard deviation for the determination of $5,30,50 \mathrm{ng} / \mathrm{mL}$ of vanadium(V) was $2.5 \% 2.6 \%, 2.4 \%$ and respectively. The method was applied to the determination of vanadium(V) in water samples.
\end{abstract}

Keywords: Vanadium(V), Malachite green oxalate (MG), Spectrophotometric, Micellar media.

\section{Introduction}

Vanadium is a biologically essential element ${ }^{1}$.Its inclusion in enzymes such as bromoperoxide and nitrogenase reveals the importace of its redox chemistry. A number of model complex systems have been investigated in order to elucidate vanadium redox mecanisms. Some tunicate fish and marin animals selectivity accumulate vanadium species 
from the ocean. Vanadium complexes, inclouding organovanadium, compound, exist in a variety of configureations depending on their oxidation states and coordination numbers ${ }^{2}$.

Vanadium in the hyposphere was believed to be a conservative element due to its almost uniform distribution in both oceanic and limnetic areas. However, slight seasonal variations with the depth of water might be encountered due to biological processes and/or the geochemical cycles of particulate vanadium and phosphorus ${ }^{3,4}$.

Vanadium in trace amounts ia an essential element for cell growth at $\mu \mathrm{g} \mathrm{dm}{ }^{-3}$ levels, but can be toxic at higher concentrations ${ }^{5}$. The toxicity of vanadium is dependent on its oxidation state $^{6}$, with vanadium(V) being more toxic than vanadium(IV). Vanadium pentoxide dust and fumes are strong respiratory irritants, owing to their capacity to lessen the viability of alveolar macrophages, which play an important role in the lung defense against environmental contaminations.The determination of vanadium has received extensiveattention because of its increasing importance in biological and environmental studies. This metal is widely distributed in the earth's crust but in low abundance.Major sources for the emission of vanadium in the environment include combustion of fuel oils, dyeing, ceramics, ink, catalyst and steel manufacturing.Vanadium in trace amounts represents an essential element for normal cell growth, but it can be toxic when present in higher concentrations ${ }^{7}$. A variety of methods have been used for determination of vanadium; these include fluorometry ${ }^{8}$, gaschromatography ${ }^{9}$, neutron activation analysis ${ }^{10,11}$, x-ray fluorescence spectrometry ${ }^{12}$, emission spectroscopy ${ }^{13}$ and atomic absorption spectroscopy ${ }^{14}$ kinetic method ${ }^{15}$. These methods either lack sufficient sensitivity or are time consuming. In order to overcome these problems, we developed and validated a rapid, sensitive and selective kinetic spectrophotometric method for the determination of vanadium $(\mathrm{V})$. This method is described based on the catalytic effect of $\mathrm{V}(\mathrm{V})$ on oxidation of Malachite green oxalate by bromate in acidic and micellar medium. The reaction was monitored spectrophotometrically at $625 \mathrm{~nm}$ by measuring for the first $0.5-2 \mathrm{~min}$ from initiation of the reaction.

\section{Experimental}

Analytical reagent grade and doubly distilled water were used. A $100 \mu \mathrm{g} / \mathrm{mL}$ stock standard solution of vanadium $(\mathrm{V})$ was prepared by dissolving $0.023 \mathrm{~g}$ of $\mathrm{NH}_{4} \mathrm{VO}_{3}$ (Merck, $\mathrm{W}=116.94$ $\mathrm{g} / \mathrm{mol}$ ) in distilled water and diluted to $100 \mathrm{~mL}$ in a $100 \mathrm{~mL}$ volumetric flask. Working solutions were prepared by appropriately diluting the stock standard solution. A $100 \mathrm{~mL}$ $0.1 \mathrm{M}$ potassium bromate solution was prepared by dissolving $1.67 \mathrm{~g}$ of $\mathrm{KBrO} 3$ (Merck, $\mathrm{MW}=167 \mathrm{~g} / \mathrm{mol}$ ) in distilled water and diluting it to mark in a $100 \mathrm{~mL}$ volumetric flask. A $1.079 \times 10^{-4} \mathrm{M}$ malachite green oxalate solution was directly prepared by dissolving $0.01 \mathrm{~g}$ of malachite green oxalate (Merck, MW=927.02 g / mol) diluting it with distilled water in a $100 \mathrm{~mL}$ volumetric flask.Trition-X-100 solution $(0.066 \mathrm{M})$ was prepared by dissolving $2 \mathrm{~mL}$ Trition-X-100 (Merck) in distilled water and diluting to $100 \mathrm{~mL}$ in a $100 \mathrm{~mL}$ volumetric flask. The other surfactants tested, namely cetyltrimethyl ammonium bromide (CTAB), cetylpyridinium chloride (CPC), sodiumdodecyl sulphate (SDS), dodecyltrimethyl ammonium bromide (DTAB), hexadecyltrimethyl ammonium boromide (HTAB), hexadecylpyridinium bromide (HDPB), tetrabutyl ammonium bromide (TBAB) and hexadecylpyridinium chloride (HCPC) were prepared in a similar way. Phosphoric acid solution $(5.0 \mathrm{M})$ was prepared by diluting a known volume of its concentrated solution (Merck). 


\section{Apparatus}

Absorption spectra were recorded with a CECIL model 7500 spectrophotometer with a $1.0 \mathrm{~cm}$ quartz cell. A model $2501 \mathrm{CECIL}$ Spectrophotometer with $1.0 \mathrm{~cm}$ glass cuvettes was used to measure the absorbance at a fixed wavelength of $625 \mathrm{~nm}$.A thermostat water batch was used to keep the reaction temperature at $20^{\circ} \mathrm{C}$. A stopwatch was used for recording the reaction times.

\section{Recommended procedure}

All the solutions and distilled water kept in thermostated water bath at $20{ }^{\circ} \mathrm{C}$ for $30 \mathrm{~min}$ before starting the experiment. The reaction monitored spectrophotometrically at $625 \mathrm{~nm}$ for the first $0.5-2 \mathrm{~min}$ from initiation of the reaction. An aliquot of the solution containing $1-100 \mathrm{ng} / \mathrm{mL}$ vanadium(V) was transferred into a $10 \mathrm{~mL}$ volumetric flask and then $1.6 \mathrm{~mL}$ of 5.0 M phosphoric acid, $1.6 \mathrm{~mL}$ of $1.079 \times 10-4 \mathrm{M} \mathrm{MG}$ and $2.8 \mathrm{~mL}$ Triton $\mathrm{x}-100$ solution were added to the flask. The solution was diluted to $8 \mathrm{~mL}$ with water, then $1.2 \mathrm{~mL} 0.1 \mathrm{M}$ potassium bromate solution was added and the solution was diluted to the mark with water. The solution was mixed and a portion of the solution was transferred to the spectrophotometic cell. The reaction was followed by measuring the decrease in absorbance of the solution against water at $625 \mathrm{~nm}$ for $0.5-2 \mathrm{~min}$ from initiation of the reaction. This signal (sample signal) was labeled as $\Delta$ As. The same procedure was repeated without addition of Vanadium(V) solution, and the signal(blank signal) was labeled as $\Delta \mathrm{Ab}$. Time was measured just after the addition of last drop of bromate. The calibration graph was constructed by plotting of $\Delta$ As versus vanadium(V) concentration at a fixed-time of 0.5-2.0 min from initiation of the reaction.

\section{Results and Discussion}

Malachite green oxalate undergoes a oxidation reaction with bromate in acidic medium at very slow rate. We found that in the presence of Triton $x-100$ as a micellar medium, the analytical signal is sharply increased by addition of trace amounts of vanadium(V). The rate equation of the catalyzed reaction is:

$$
\begin{aligned}
& \text { Rate }=-\mathrm{d}[\text { Malachite green oxalate }] / \mathrm{dt} \\
& =\mathrm{K}[\text { Vanadium }(\mathrm{V})][\text { Malachite green oxalate }]^{\mathrm{m}}\left[\mathrm{BrO}_{3}^{-}\right]^{\mathrm{n}}
\end{aligned}
$$

Were $\mathrm{k}$ is the rate constant. Because $\left[\mathrm{BrO}_{3}{ }^{-}\right.$], [Malachite green oxalate], $\mathrm{BrO}_{3}{ }^{-}$can be considered to be constant and $\mathrm{m}$ was found to be 1 . By integration of Eq[1] and by incorporating Beer's law, we obtain the final expression:

$$
\Delta \mathrm{A}=\mathrm{K}[\operatorname{Vanadium}(\mathrm{V})] \mathrm{t}
$$

Where, $\mathrm{t}$ is the reaction time Figure 1 . There are many methods, such as fixed-time, initial rate, rate constant and variable time methods for measuring the catalytic species, the fixed-time method is the most conventional and simplest, involving the measurement of $\Delta \mathrm{A}$ at $625 \mathrm{~nm}$. Figure 1 shows the relationship between A and reaction time. It was found that the rate of reaction is proportional to the vanadium $(\mathrm{V})$ concentration. The reaction rate was monitored spectrophotometrically by measuring the decrease in absorbance of the characteristic band of malachite green oxalate at $625 \mathrm{~nm}$. Therefore, by measuring the decrease in absorbance of MG for a fixed time of 0.5-2.0 min from initiation of the reaction, the vanadium $(\mathrm{V})$ contents in the sample can be measured. Malachite green oxalate has the following structure (Figure 2). 


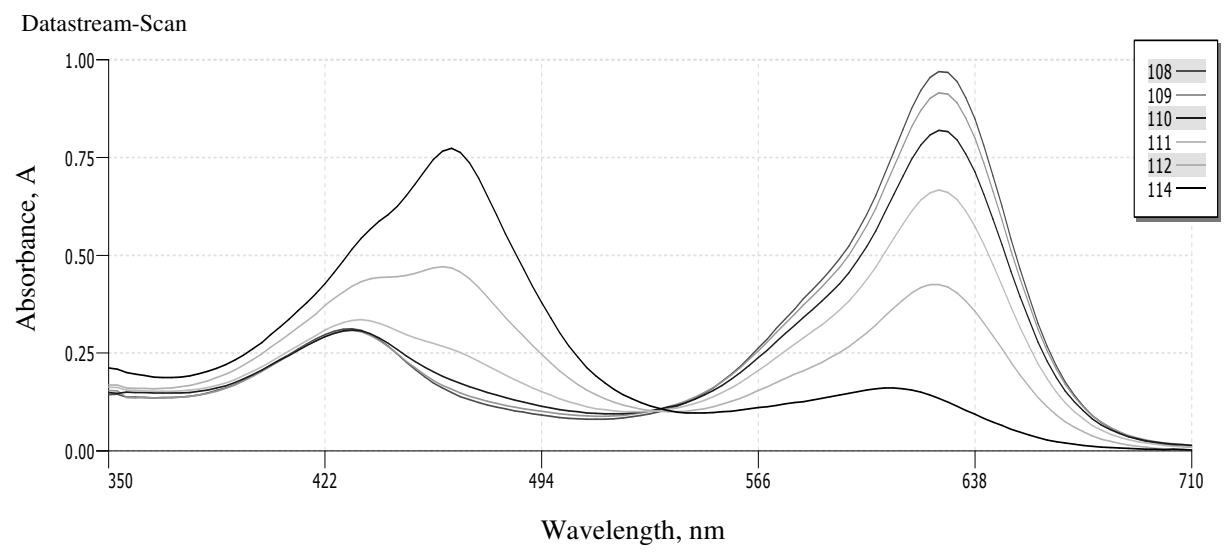

Figure 1. Absorption spectrum for the vanadium(V) $-\mathrm{MG}^{-} \mathrm{BrO}_{3}{ }^{-}$system with time. Conditions: $0.8 \quad \mathrm{M} \mathrm{H}_{3} \mathrm{PO}_{4} ; 100 \mathrm{~g} / \mathrm{mL} \mathrm{V}(\mathrm{V}) ; 2.8 \times 10^{-2} \mathrm{M}$ Triton-X-100;1.72×10 $0^{-5} \mathrm{M}$ MG; $1.2 \times 10^{-2} \mathrm{M} \mathrm{BrO}_{3}^{-}$; temperature, $20{ }^{\circ} \mathrm{C}$; interval time for each scan, 0.5, 1.0, 1.5, $2,2.5$ and $3.5 \mathrm{~min}$ from initiation of the reaction<smiles>CN(C)c1ccc(C(=C2C=CC(=[N+](C)C)C=C2)c2ccccc2)cc1</smiles>

Figure 2. Structure of malachite green oxalate

\section{Optimization of variables}

The influence of phosphoric acid concentration, malachite green oxalate concentration, bromated concentration, the effect of deferent kinds of surfactantants, surfactant concentration and temperature on the analytical signal was studied. to find the optimum conditions.

The effect of $\mathrm{H}_{3} \mathrm{PO}_{4}$ concentration on the sensitivity was studied in the range of $0.6 \mathrm{M}$ to $1 \mathrm{M}$ in the presence of $100 \mathrm{ng} / \mathrm{mL} \mathrm{V(V)} \mathrm{(Figure} \mathrm{3),} \mathrm{The} \mathrm{results} \mathrm{show} \mathrm{that} \mathrm{the} \mathrm{analytical} \mathrm{signal} \mathrm{increases}$ with increasing sulfuric acid concentration up to $0.8 \mathrm{M}$ and decreases at higher concentrations. This mean that the rate of uncatalyzed reaction increases with phosphoric acid concentration $(>0.8 \mathrm{M})$ to a greater extent than the catalyzed reaction and the difference between the rates of catalyzed and uncatalyzed reactions $\Delta \mathrm{A}_{\mathrm{s}}-\Delta \mathrm{A}_{\mathrm{b}}$ diminishes at higher phosphoric acid concentrations. Therefore, a phosphoric acid concentration of $0.8 \mathrm{M}$ was selected for further study.

Figure 4 shows the influence of MG concentration on the analytical signal in the range of $1.07 \times 10^{-5} \mathrm{M}$ to $2.15 \times 10^{-5} \mathrm{M}$. The results show that by increasing MG concentration up to $1.72 \times 10^{-5} \mathrm{M}$, the analytical signal increases, whereas greater amounts of the dye decrease the analytical signal. This may be due to the aggregation of the dye in higher concentration. Therefore, a MG concentration of $1.72 \times 10^{-5} \mathrm{M}$ was selected for further study.

The effect of bromate concentration on the analytical signal was studied in the range of $0.8 \times 10^{-2} \mathrm{M}$ to $1.6 \times 10^{-2} \mathrm{M}$. The results show that the analytical signal increases with bromate concentration up to $1.2 \times 10^{-2} \mathrm{M}$, whereas the analytical signal decreases with increasing bromate concentration from $1.2 \times 10^{-2} \mathrm{M}$ to greater values. This means that the rate 
of uncatalyzed reaction increases with bromate concentration $\left(>1.2 \times 10^{-2} \mathrm{M}\right)$ to a greater extent than the catalyzed reaction and the difference between the rates of catalyzed and uncatalyzed reaction $\left(\Delta \mathrm{A}_{\mathrm{s}}-\Delta \mathrm{A}_{\mathrm{b}}\right)$ diminishes at higher bromate concentration. Thus, a bromate concentration of $1.2 \times 10^{-2} \mathrm{M}$ was selected for further study.

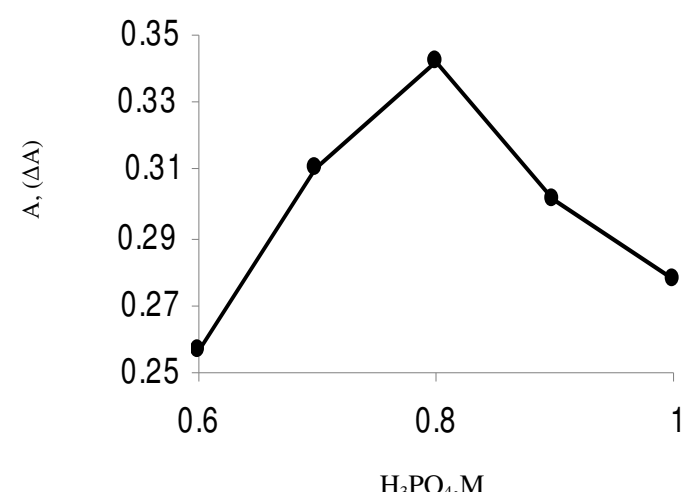

Figure 3. Effect of $\mathrm{H}_{3} \mathrm{PO}_{4}$ concentration on the sensitivity. Conditions: $100 \mathrm{ng} / \mathrm{mL}$

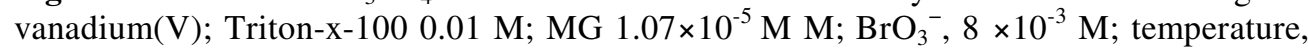
$23{ }^{\circ} \mathrm{C}$ and time of .5-2.0 min from initiation of the reaction

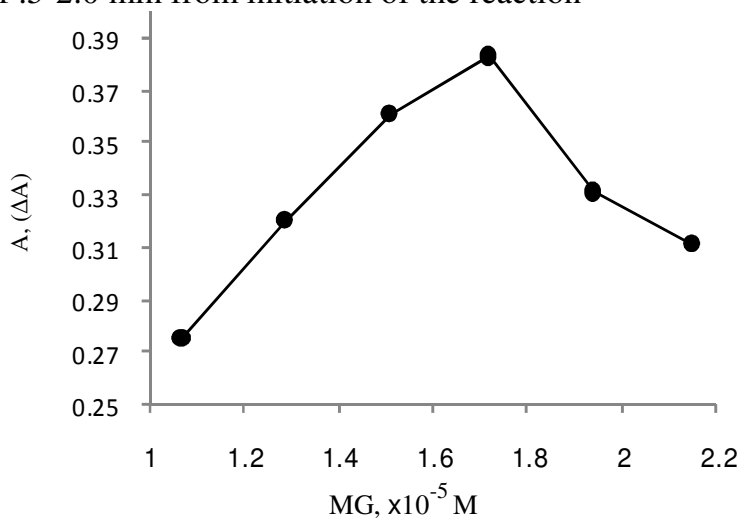

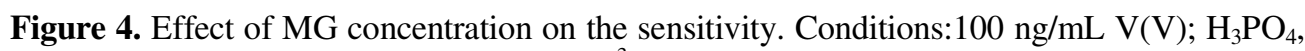
$0.8 \mathrm{M}$; Triton-X-100, $0.01 \mathrm{M}$; $\mathrm{BrO}_{3}{ }^{-}, 8 \times 10^{-3} \mathrm{M}$; temperature, $23{ }^{\circ} \mathrm{C}$ and time of 2.0 min from initiation of the reaction

In many reactions, Suitable micelles can affect the rate of reactions ${ }^{16-23}$. A micelle usually can be formed by aggregation of charged organic molecules. These micelles have the same charge at the outer sphere. For those reactions which have charged species, these micelles can affect the rate of reaction by increasing the effective collisions. In order to choose an appropriate micellar system to enhance the rate of reaction, one should take into account the type of charge of the reactants, because the accelerating effect of micelles arises essentially due to electrostatic and hydrophobic interactions between the reaction and micellar surfaces ${ }^{24}$. Cationic (CTAB, CPC, DTAB, HDPB, HTAB, TBAB, HCPC), anionic (SDS) and nonionic (Triton- $\mathrm{x}-100)$ micelles were tested at a concentration greater than the critical micelle concentration (C.M.C). The results are shown in Table 1. In fact, Triton-X-100, DTAB, TBAB and HDPC increased sensitivity, but Triton- -100 increased sensitivity more than DTAB, TBAB and HDPC; thus, Triton- $x-100$ was chosen for further study. Table 1. 


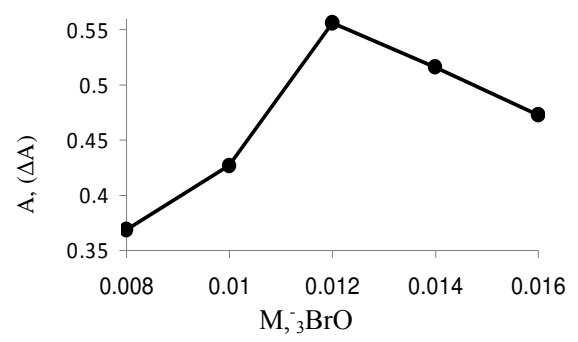

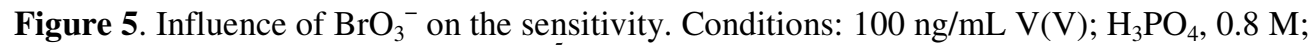
Triton-X-100, $0.01 \mathrm{M}$; MG, $1.72 \times 10^{-5} \mathrm{M}$; temperature, $23{ }^{\circ} \mathrm{C}$ and time of $2.0 \mathrm{~min}$ from initiation of the reaction

Table 1. Surfactant tested us a potential micellar catalyst for the enhanced rate of $\mathrm{MG}-\mathrm{BrO}_{3}$ $-\mathrm{V}(\mathrm{V})$ reaction

\begin{tabular}{cccc}
\hline Surfactant & Type & CMC, M & Micellar catalysis \\
\hline Tritonx100 & Nonionic & $3.0 \times 10^{-4}$ & Positive \\
DTAB & Cationic & $1.5 \times 10^{-2}$ & Positive \\
HDPC & Cationic & $2.4 \times 10^{-4}$ & Positive \\
TBAB & Cationic & $7.5 \times 10^{-5}$ & Positive \\
CPC & Cationic & $1.2 \times 10^{-4}$ & Positive \\
CTAB & Cationic & $1.3 \times 10^{-4}$ & Positive \\
HDPB & Cationic & $6.5 \times 10^{-4}$ & Negative \\
HTAB & Cationic & $9.2 \times 10^{-4}$ & Negative \\
SDS & Anionic & $8.1 \times 10^{-4}$ & Negative \\
\hline
\end{tabular}

The effect of the Triton- $\mathrm{X}-100$ concentration on the analytical signal was studied in the range of $0 \mathrm{M}$ to $3.6 \times 10^{-2} \mathrm{M}$ (Figure 6 ). the analytical signal increases with increasing Triton- $\mathrm{X}-100$ concentration up to $2.8 \times 10^{-2} \mathrm{M}$ and decreases at higher concentrations. Therefore a final concentration of $2.8 \times 10^{-2} \mathrm{M}$ was selected as the optimum concentration of Triton-X-100 for further study. The effect of the temperature on the sensitivity was studied in the range $10-30{ }^{\circ} \mathrm{C}$ with the optimum of the reagents concentrations. The results showed that, as the temerature increases up to $20^{\circ} \mathrm{C}$, the analytical signal increases, whereas higher temperature values decrease thev analytical signal $\left(\Delta \mathrm{A}=\Delta \mathrm{A}_{\mathrm{s}}-\Delta \mathrm{A}_{\mathrm{b}}\right)$, Therefore, $20^{\circ} \mathrm{C}$ was selected for further study.

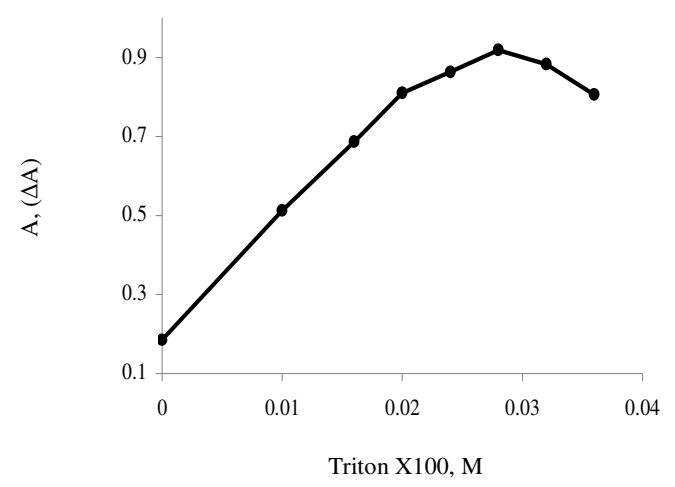

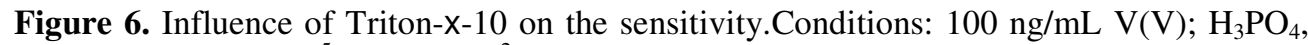
$0.8 \mathrm{M}$; MG, $1.72 \times 10^{-5} \mathrm{M} ; 1.2 \times 10^{-2} \mathrm{M} \mathrm{BrO}_{3}^{-}$; temperature, $23{ }^{\circ} \mathrm{C}$ and time of 2.0 min from initiation of the reaction 


\section{Calibration graph, detection limit, reproducibility and accuracy}

The calibration graph was linear for Vanadium(V) concentration in the range of 0.1-10 $\mathrm{ng} / \mathrm{mL}$ with the regression equation of $\Delta \mathrm{A}=0.007 \mathrm{C}+0.158$ with $(\mathrm{r}=0.999 \mathrm{n}=9)$ where $\Delta \mathrm{A}$ is change in absorbance for the sample reaction for $0.5-2.0 \mathrm{~min}$ from initiation of the reaction (catalytic reaction) and $\mathrm{C}$ is the $\mathrm{Vanadium}(\mathrm{V})$ concentration in $\mathrm{ng} / \mathrm{mL}$. The limit of detection (Defined as $C L=3 S_{b} / m$, where $C_{L}, S_{b}$ and $m$ are limit of detection, standard deviation of the blank signal and slope of the calibration graph, respectively) is equal to $0.71 \mathrm{ng} / \mathrm{mL}$ Vanadium(V). The relative standard deviations (R.S.D.) for ten replicate determination of $30,40,50$ and $5 \mathrm{ng} / \mathrm{mL}$ Vanadium(V) is $2.6 \%, 2.8 \%, 2.4 \%$ and $2.5 \%$ respectively.

\section{Interference study}

More than 25 foreign substances in solution were studied for the possible influence on the determination of vanadium $(\mathrm{V})$ by the proposed method. The maximum amount of substance causing an error of more than $3 \%$ in the determination of $100 \mathrm{ng} / \mathrm{mL}$ vanadium(V) was taken as the tolerance limit. The results are showed in Table 2 . The results show that the method is relatively selective.

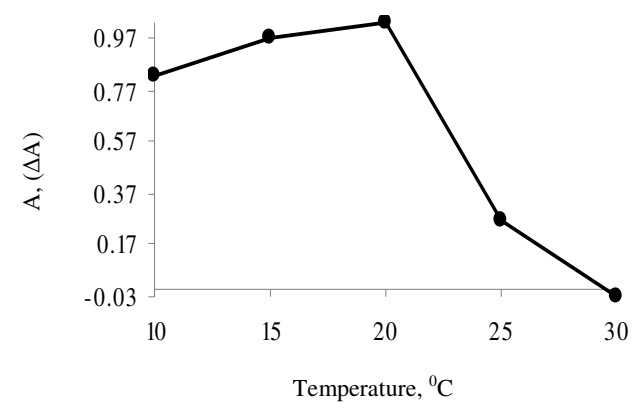

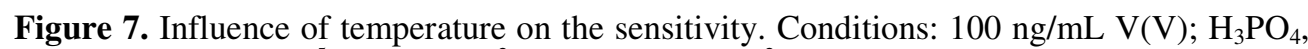
$0.8 \mathrm{M}$; MG $1.72 \times 10^{-5} \mathrm{M} ; 1.2 \times 10^{-2} \mathrm{M} \mathrm{BrO}_{3}^{-} ; 2.8 \times 10^{-2} \mathrm{M}$; Triton $\mathrm{x}-100$ and time of $2.0 \mathrm{~min}$ from initiation of the reaction

Table 2. Effect of foreign ions on the determination of $100 \mathrm{ng} / \mathrm{mL} \mathrm{V(V)}$

\begin{tabular}{cc}
\hline Species & Tolerance Limit(w ion/w V(V)) \\
\hline $\mathrm{Na}^{+}, \mathrm{K}^{+}, \mathrm{Mg}^{2+}, \mathrm{Ni}^{2+}, \mathrm{Cd}^{2+}, \mathrm{Zn}^{2+}, \mathrm{Cr}^{2+}, \mathrm{Al}^{3+}$, & \\
$\mathrm{Cu}(\mathrm{II}), \mathrm{Pb}(\mathrm{II}), \mathrm{Se}(\mathrm{IV}), \mathrm{Mn}(\mathrm{II}), \mathrm{Co}(\mathrm{II}), \mathrm{ClO}_{3}{ }^{-}$ & \\
$, \mathrm{SO}_{3}{ }^{2-}, \mathrm{IO}_{3}{ }^{-}, \mathrm{PO}_{4}{ }^{3-}, \mathrm{CH}_{3} \mathrm{COO}^{-}, \mathrm{BO}_{3}{ }^{2-}$ & 8000 \\
$\mathrm{IO}_{4}^{-}$ & 100 \\
$\mathrm{Pd}^{2+}$ & 50 \\
$\mathrm{Rh}^{3+}, \mathrm{Ru}^{(\mathrm{III})}, \mathrm{Mo}(\mathrm{VI})$ & Inhibited \\
$\mathrm{Cl}^{-}, \mathrm{I}^{-}$ & \\
\hline
\end{tabular}

\section{Application of the method}

In order to evaluate the applicability of the proposed method, real and synthetic water samples were analyzed to determine vanadium(V) contents. The results are presented in Table 3. Good recoveries and precise results show good reproducibility and accuracy of the method. The kinetic-spectrophotometric method developed for the determination of vanadium(V) is inexpensive, employs available reagents, allows rapid determination 
at low operating costs, provides simplicity, adequate selectivity, a low limit of detection compared to other kinetic procedures. Using this method, it is possible to determine vanadium(V) at levels as low as $1 \mathrm{ng} / \mathrm{mL}$ without the need for any preconcentration steps.

Table 3. Determination of $\mathrm{V}(\mathrm{V})$ added to water samples

\begin{tabular}{ccccc}
\hline Sample & $\begin{array}{c}\mathrm{V}(\mathrm{V}) \text { added, } \\
\mathrm{ng} / \mathrm{mL}\end{array}$ & $\begin{array}{c}\mathrm{V}(\mathrm{V}) \text { found, } \\
\mathrm{ng} / \mathrm{mL}\end{array}$ & $\begin{array}{c}\text { Recovery, } \\
\%\end{array}$ & $\begin{array}{c}\text { RSD, \% } \\
\mathrm{n}=5\end{array}$ \\
\hline Well water & 5 & 4.8 & 96 & 2.5 \\
Well water & 30 & 28 & 93 & 2.6 \\
Well water & 40 & 44 & 110 & 2.8 \\
Well water & 50 & 48 & 96 & 2.4 \\
\hline
\end{tabular}

Table 4. Comparison of kinetic spectrophotometry methods for determination of Vanadium(V) with proposed method

\begin{tabular}{cccc}
\hline Method & $\mathrm{DL}, \mu \mathrm{g} / \mathrm{mL}$ & $\mathrm{LDR}, \mu \mathrm{g} / \mathrm{mL}$ & Reference no. \\
\hline Catalytic Spectrophotometry & 1 & $4.1-33.3$ & 25 \\
Catalytic Spectrophotometry & 4 & $400-4000$ & 26 \\
Catalytic Spectrophotometry & 0.02 & $0-2.5$ & 27 \\
Catalytic Spectrophotometry & 0.5 & $1-240$ & 28 \\
Catalytic Spectrophotometry & 0.01 & $0.05-8.0$ & 29 \\
Catalytic Spectrophotometry & 3 & $4-520$ & 30 \\
Catalytic Spectrophotometry & .0088 & $0.05-50$ & 31 \\
Catalytic Spectrophotometry & 0.01 & $0-0.5$ & 32 \\
Proposed Method & 0.00071 & $0.001-0.1$ & - \\
\hline
\end{tabular}

\section{Conclusion}

The kinetic-spectrophotometric method developed for vanadium(V) determination in water is inexpensive and readily available and allows rapid determination at low operating costs and shows simplicity, adequate selectivity, comparison of detection limit and linear dynamic range of several kinetic spectrophotometric methods with proposed method showed in Table 4. Using this method, it is possible to determine vanadium(V) at levels as low as 1 $\mathrm{ng} / \mathrm{mL}$ without the need for any preconcentration steps. Therefore, the method could be proposed for environmental analyses.

\section{Acknowledgment}

The authors express their gratitude to the Center of Excellency in Science of Islamic Azad University Majlesi and the shahreza Branch for support of this work.

\section{References}

1. Hirao T, Chem Rev., 1997, 97, 2707.

2. Cotton F A and Wilkinson G, Advanced Inorganic Chemistry; John Wiley Sons Inc.: New York, 1980.

3. Collier R W, Nature, London, 1984, 309, 441.

4. Sherrell R M and Boyle E A, Zinc Deep-Sea Res., 1988, 35,1319-1334.

5. Tallor M J C and van staden J F, Review Anal., 1994, 119, 1263-1276.

6. Patel B, Henderson G E, Hasell S J and Grzeskowiak R,.Analyst, 1990, 115, 1063-1066.

7. Pyrzynska K, Microchim Acta., 2005, 149, 159. 
8. Yu Y, Hong C, Wo Z, Wang R and Huang J, Fenxi Huaxue., 1996, 24, 479.

9. Sievers, R.E., B.W. Ponder, Morris M L and Moshier R W, Inorg Chem., 1963, 2, 693.

10. Eissa E A, Rofail N B, Ali R A and Hassan A M, Phys Chem., 1996, 47(5), 705-708.

11. Kucera J, Lener J, Soukol L and Horakova J, J Trace Microprobe Tech., 1996, 14, 191.

12. Wildhagen D, Krivan V, Gerchen B and Pavel J, J Anal At Spectrom, 1996, 11, 371.

13. Lander J, Steiner D W, Anderson D H and Dehm R L, Appl Spectrosc, 1971, 25, 270-275.

14. Korkisch and Gross H, Asian J Chem Spectrophotometry Talanta, 1973, 20, 1153.

15. Keyvanfard M, World Aplied Science Journal., 2009, 6(5), 624-629.

16. Ensafi A A and Keyvanfard M, Anal Lett., 2002, 35(2), 423-433.

17. Ensafi A A and Keyvanfard M, International J Environ Anal Chem., 2003, 83(5), 397-404.

18. Ensafi A A and Keyvanfard M, J Anal Chem., 2003, 58(11), 1060-1064.

19. Keyvanfard M and Karamian M, Asian J Chem., 2009, 21(2), 942-948.

20. Keyvanfard M, Asian J Chem., 2009, 21(4), 2715-2720.

21. Keyvanfard M, Asian J Chem., 2009, 21(2), 983-988.

22. Keyvanfard M, Asian J Chem., 2009, 21(2), 989-996.

23. Keyvanfard M, Asian J Chem., 2009, 21(3), 2119-2125.

24. Rubio S and Perez-Bendito D, Anal Chem Acta., 1989, 224, 185

25. Balaji B K, Saravanakumur G, Murugesan P and Mishra G, Talanta, 1998, 46, 1299-1304.

26. Sikalos T S, Arabatzis Y M, Prodromidis M I, Veltsistas P G and Karayannis M I, Microchimica Acta, 2000, 135(3-4), 197.

27. Yamane T, Osaka Y and Suzuki M, Talanta, 1998, 45, 583.

28. Zhang Z Q, Liu X P and Zhan H Y, Anal Lett., 1999, 32, 2115-2116.

29. Shiobara T, Teshima N, Kurihara M, Nakano S and Kawashima T, Talanta, 1999, 49, 1083.

30. Ensafi A A, Amini M K and Mazeloum M, Anal Lett., 1999, 32, 1927-1937.

31. Gao J, Zhang X, Yang W and Kang J, Anal Chim Acta, 2002, 455, 159-165.

32. BaI L, Zhang W, Liu X and Liang L Rare Metals, 2007, 26, 85. 


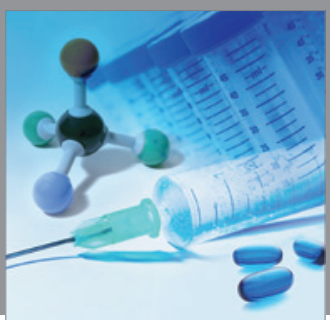

International Journal of

Medicinal Chemistry

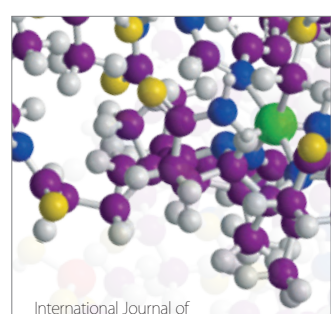

Carbohydrate Chemistry

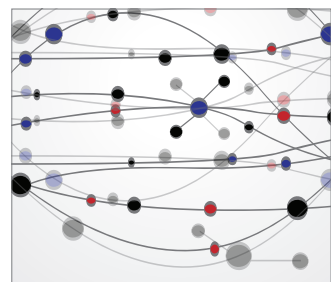

The Scientific World Journal
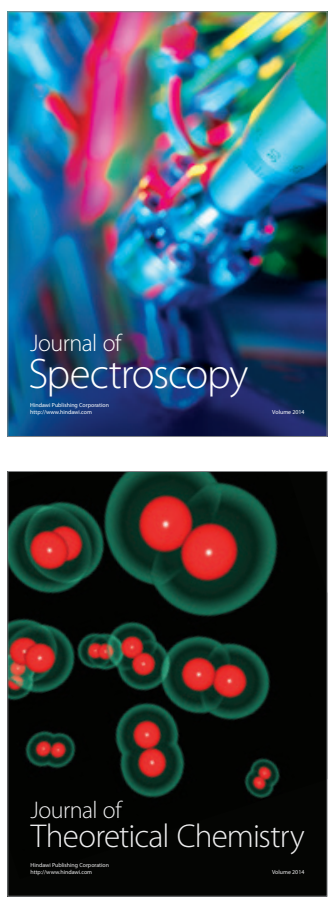
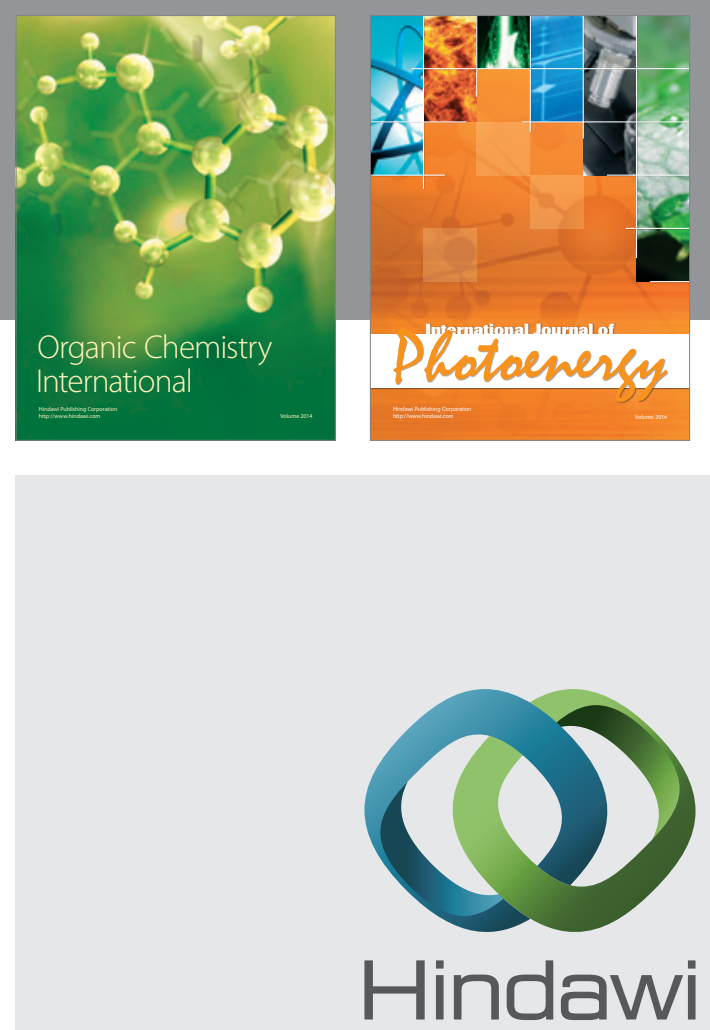

Submit your manuscripts at

http://www.hindawi.com
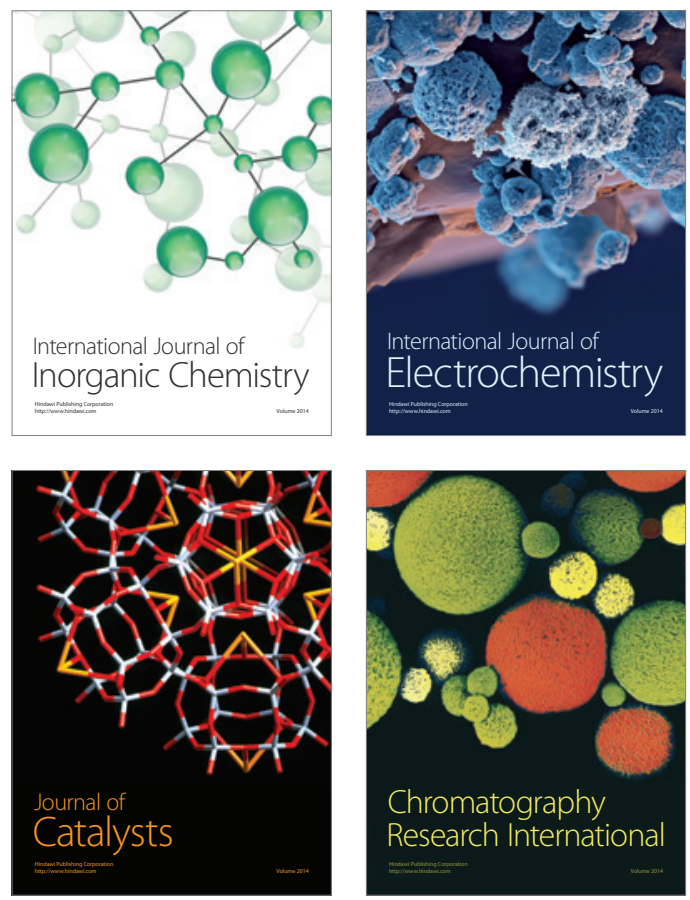
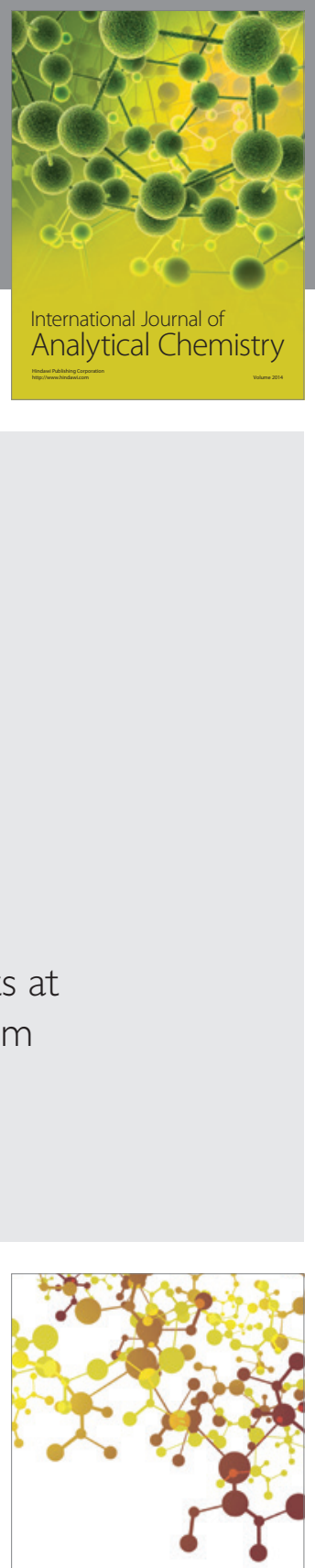

Journal of

Applied Chemistry
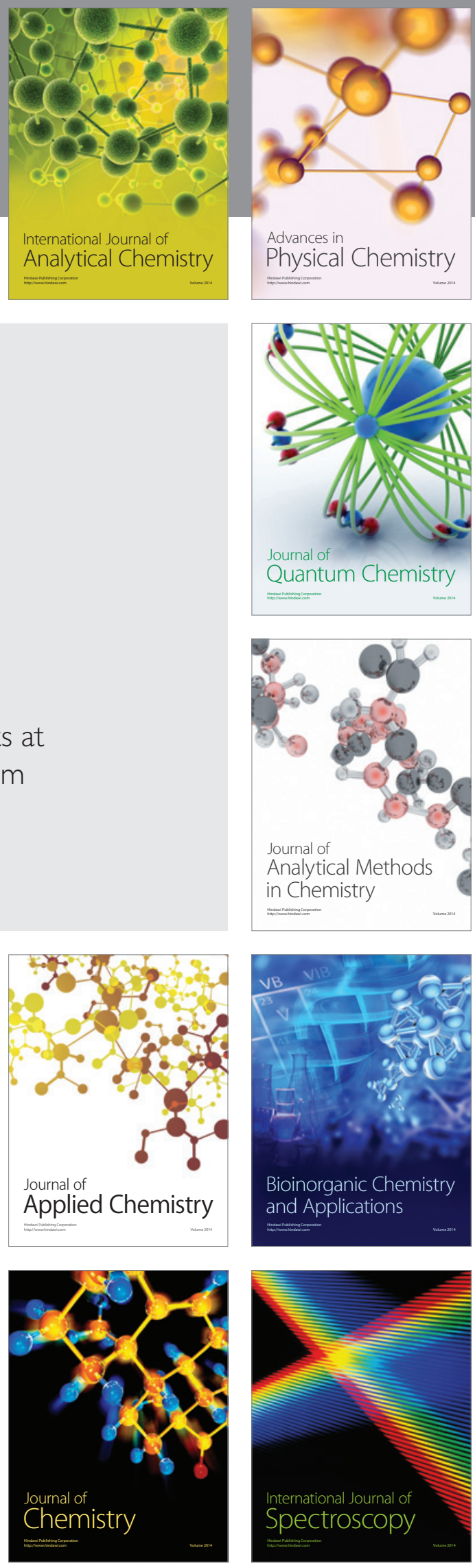